Изв. АН Эстонии. Геол., 1992, 41, 3, 124-138

удК $551.73(474)$

Кайса МЕНС*, Анне КЛЕЕСМЕНТ*, Сильви МЯГИ*, Тынис СААДРЕ*, Рейн ЭЙНАСТО*

\title{
РАЗРЕЗ КАЛЕДОНСКОГО СТРУКТУРНОГО КОМПЛЕКСА ЗАПАДА ПРИБАЛТИКИ (ПО ЛИНИИ ТАХКУНА-ГОЛДАП)
}

Каледонский структурный комплекс охватывает отложения от постбалтийского раннего кембрия до лохковского века раннего девона включительно. В зависимости от структурного плана распространения и литологической характеристики пород рассматриваемый структурный комплекс разделен на два подкомплекса. Нижний подкомплекс, заканчивающийся тремадокскими песчано-алевритовыми образованиями, сложен в основном терригенными породами, верхний - глинисто-карбонатными. Эти подкомплексы, кроме вещественного состава, различаются по мощностям и количеству перерывов. Оба эти показателя, кроме тектонического режима седиментации на краю платформы, в значительной степени определены развитием как региональных, так и локальных структур.

Каледонский этап тектонического развития Восточно-Европейской платформы охватывает время с середины раннего кембрия (с начала т. н. трилобитового кембрия) до низов раннего девона включнтельно, продолжительностью около 170 млн. лет согласно геохронологическим датировкам (Харленд и др., 1985). Отложения этого временного интервала сравнительно широко развиты на территории Прибалтики и относительно хорошо изучены стратиграфически, литологически, в фациальном аспекте и палеогеографически. В свете сказанного в данной статье сделана попытка выявить закономерности и особенности хода седиментации в пространстве и во времени - в течение одного тектонического цикла. Представленный здесь материал базируется на результатах изучения керна буровых скважин, расположенных между двумя современными положительными структурами - южным склоном Балтийского щита на севере и Мазурско-Белорусской антеклизой на юге (рис. 1). Данный профиль является стратиграфически наиболее полным по всей Прибалтике.

Согласно тектонической терминологии Прибалтики, отложения каледонского этапа развития образуют каледонский структурный комплекс, который, в свою очередь, расчленяется на два подкомплекса: нижний - терригенный и верхний - глинисто-карбонатный (Тектоника ..., 1979).

Қаледонский структурный комплекс сложен надбалтийскими кембрийскими, ордовикскими, силурийскими и нижнедевонскими ( лохковскими) отложениями. Стратиграфическое расчленение отложений этих систем дано в статье согласно последним стратиграфическим схемам кембрийских (Решение ..., 1986), ордовикских и силурийских (Решения ..., 1987), девонских (Rzhonshitskaya, 1988) отложений ВосточноЕвропейской платформы.

* Eesti Teaduste Akadeemia Geoloogia Instituut (Институт геологии Академии наук Эстонии). EE0105 Tallinn, Estonia pst. 7. Estonia. 
рис. 1. Схема расположения разрезов, приведенных на рис. $2-5$. Скважины: 1 - Тахкуна, 2 - Курису, 3 - Эммасте, 4 - Эйкла, 5 Вики, 6 - Каугатума, 7 - Охесааре, 8 - Колка 54, 9 - Овиши, 10 -

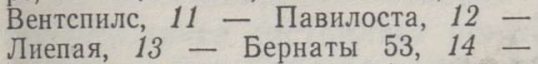
Папе 95,15 - Генчяй 4,16 - Стонишкяй, $17-$ Голдап.

Fig. 1. Location of the borings shown in Figs. 2-5.

Borings: 1 - Tahkuna, 2 - Kurisu, 3 - Emmaste, 4 - Eikla, 5 - Viki, 6 - Kaugatuma, 7 - Ohesaare, 8 Kolka 54, 9-Oviši, 10 - Ventspils, 11 - Pavilosta, 12 - Liepaja, 13 - Bernate 53,14 - Pape 95, 15 - Genčiai 4, 16 - Stoniškiai, 17 - Goldap.

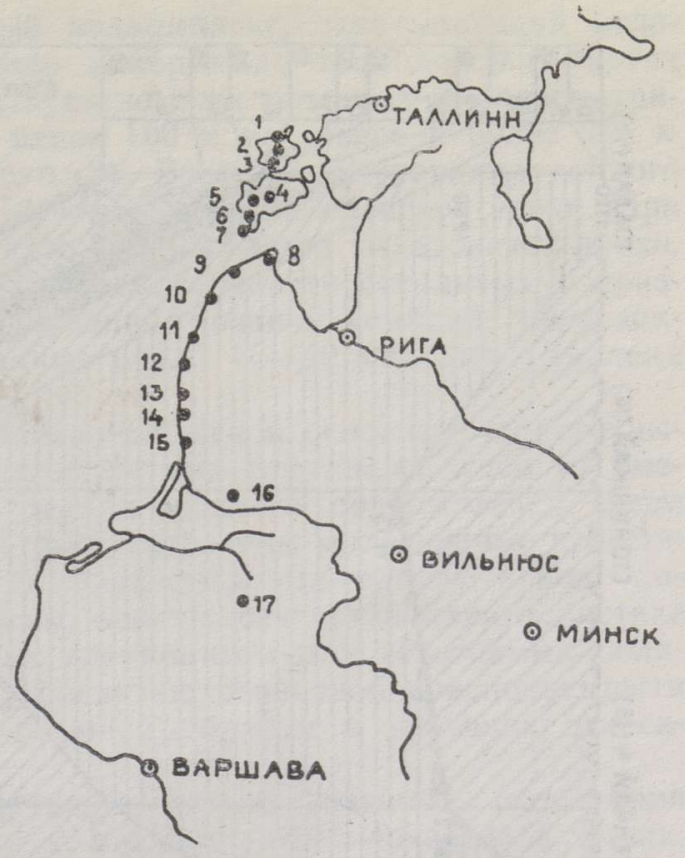

Снизу и сверху комплекс отделен региональными перерывами и угловыми несогласиями. Так, нижняя граница комплекса на рассматриваемой территории совпадает с крупным перерывом в седиментации, сопровождаемым существенным изменением структурного плана осадконакопления всей западной части Восточно-Европейской платформы (Менс, Пиррус, 1979). Четким седиментационным перерывом маркируется также верхняя граница каледонского структурного комплекса - лохковские отложения Балтийской синеклизы относятся к эмерсивной фазе рассматриваемого тектонического цикла. Последующие, пражские отложения, отделенные от лохковских стратиграфическим пробелом, являются уже начальными образованиями герцинского комплекса. На рубеже лохковского и пражского веков наблюдаются также существенные изменения структурного плана осадконакопления всего региона (Нарбутас, 1987).

Отложения всего каледонского структурного комплекса представляют собой самостоятельный трансгрессивный-регрессивный циклит высокого порядка морской седиментации, внутреннее строение которого отражает эволюцию тектонического режима западного края ВосточноЕвропейской платформы. Мощность отложений этого циклита, кроме местоположения в бассейне седиментации, обусловлена интенсивностью постседиментационной денудации и на рассматриваемом профиле изменяется от 147 м в разрезе скв. Тахкуна до 1105 м в разрезе скв. Стонишкяй (рис. 2). На основе общей литологической характеристики отложений по разрезам, а также с учетом их глинистости, первичной красноцветности, структуры, текстуры и наличия стратиграфических пробелов выделенные парагенетические комплексы пород ниже обозначены как макрофации. Путем прослеживания изменений этих комплексов по разрезу и по площади вскрыты переломные моменты осадконакопления внутри каледонской эпохи.

По нижнему подкомплексу материалы составлены и обобщены К. Менс, по ордовикско-силурийским отложениям верхнего подкомплекса - С. Мяги, Т. Саадре и Р. Эйнасто, а по нижнедевонским А. Клеесмент. 


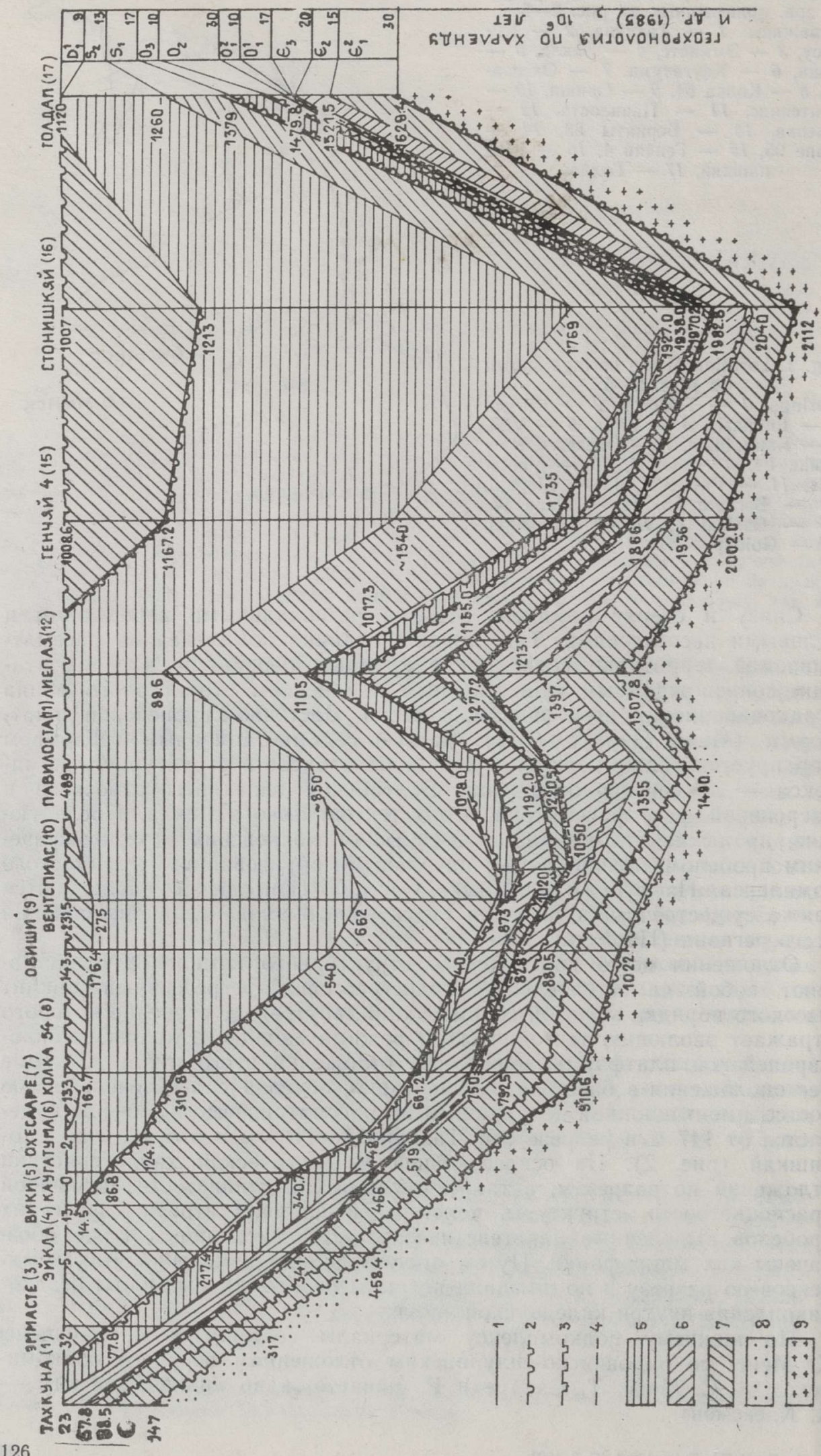


Раннекаледонский структурный подкомплекс, охватывающий отложения от постбалтийского раннего кембрия до тремадокского яруса ордовика включительно, присутствует во всех разрезах на рассматриваемом профиле, его мощность менее 100 м на севере и более 200 м в районе Павилоста-Лиепая (рис. 2). Время формирования данного подкомплекса составляет почти половину всей каледонской эпохи. При этом на долю раннего кембрия, входящего в состав каледонской эпохи, приходится около 30 млн. лет, продолжительности остальных подразделений нижнего подкомплекса (средний, поздний кембрий, тремадокский век) почти равны и составляют около 15-20 млн. лет (Харленд и др., 1985).

Нижний структурный подкомплекс сложен в основном терригенными породами - песчаниками, алевролитами и глинами, либо их смешанными разностями. Лишь в верхах нижнего подкомплекса среди кварцевых алевролитов мозаично распространены маломощные прослои керогенсодержащих аргиллитов и брахиоподовых ракушечников. Согласно палеонтологическим данным, минералогической характеристике отложений, наличию обогащенных глауконитом или гётитовыми оолитами уровней и незначительному развитию первичной красноцветности эти отложения формировались главным образом в условиях относительно неглубокого шельфа.

Нижний структурный подкомплекс рассматриваемой территории отличается от верхнего, особенно от его силурийско-лохковской толщи, незначительной мощностью, наличием множества стратиграфических пробелов и незначительной дифференциацией одновозрастных отложений по латерали (рис. 2). Сказанное весьма ограничивает использование фациального анализа отложений для восстановления хода осадконакопления в первой половине каледонской эпохи.

Согласно формационному расчленению разрезов венда и кембрия Прибалтики (Брангулис и др., 1987), в строении нижнего подкомплекса участвуют три морские формации (снизу вверх): сероцветная алеврито-глинистая (ливская и айсчяйская серии), песчано-алевритовая (дейменская серия) и керогенсодержащая карбонатно-терригенная (постдейменский средний кембрий-тремадок), входящие в вертикальный ряд терригенных формаций. Характер и распределение типов пород

Рис. 2. Стратиграфический разрез отложений каледонского структурного комплекса по линии Тахкуна-Голдап.

1 - границы систем и отделов, 2 - основные стратиграфические пробелы, 3 внемасштабные стратиграфические подразделения, 4 - граница между подкомплексами, 5 - верхний отдел, 6 - средний отдел, 7 - нижний отдел, 8-9 - подстилающие породы: 8 - осадочного чехла, 9 - кристаллического фундамента.

Номера в скобках рядом с названием скважин (рис. 2-5) указывают на их положение на рис. 1 .

Стратиграфические индексы, отличающиеся от общепринятых: $\mathcal{C}_{1}^{2}-$ постбалтийский ранний кембрий, $\mathrm{O}_{1}^{1}-$ тремадок, $\mathrm{O}_{1}^{2}-$ посттремадокский ранний ордовик, $\mathrm{D}_{1}^{1}-$ лохков.

Fig. 2. Stratigraphical cross section of the Caledonian structural complex along the Tahkuna-Goldap line.

1 - boundàries between systems and series, 2 - main discontinuity surfaces, 3 out-of-scale stratigraphical unit, 4 - boundary between subcomplexes, 5 - upper series, 6 - middle seríes, 7 - lower series, 8-9-underlying rocks: 8 - of the sedimentary cover, 9 - of the crystalline basement.

The numbers in brackets (Figs. 2-5) show the location of boreholes in Fig. 1.

Non-standard indexes: $\mathrm{C}_{1}^{2}-$ post-Baltian early Cambrian, $\mathrm{O}_{1}^{1}-$ Tremadoc, $\mathrm{O}_{1}^{2}$.... post-Tremadocian early Ordovician, $\mathrm{D}_{1}^{1}$ - Lochkov. 
в пределах этих формаций, как и стратиграфическая полнота разрезов̈ нижнего структурного подкомплекса, обусловлены, помимо тектонического режима седиментации в мелководном шельфе на окраине платформы, развитием на рассматриваемой территории локальных тектонических структур.
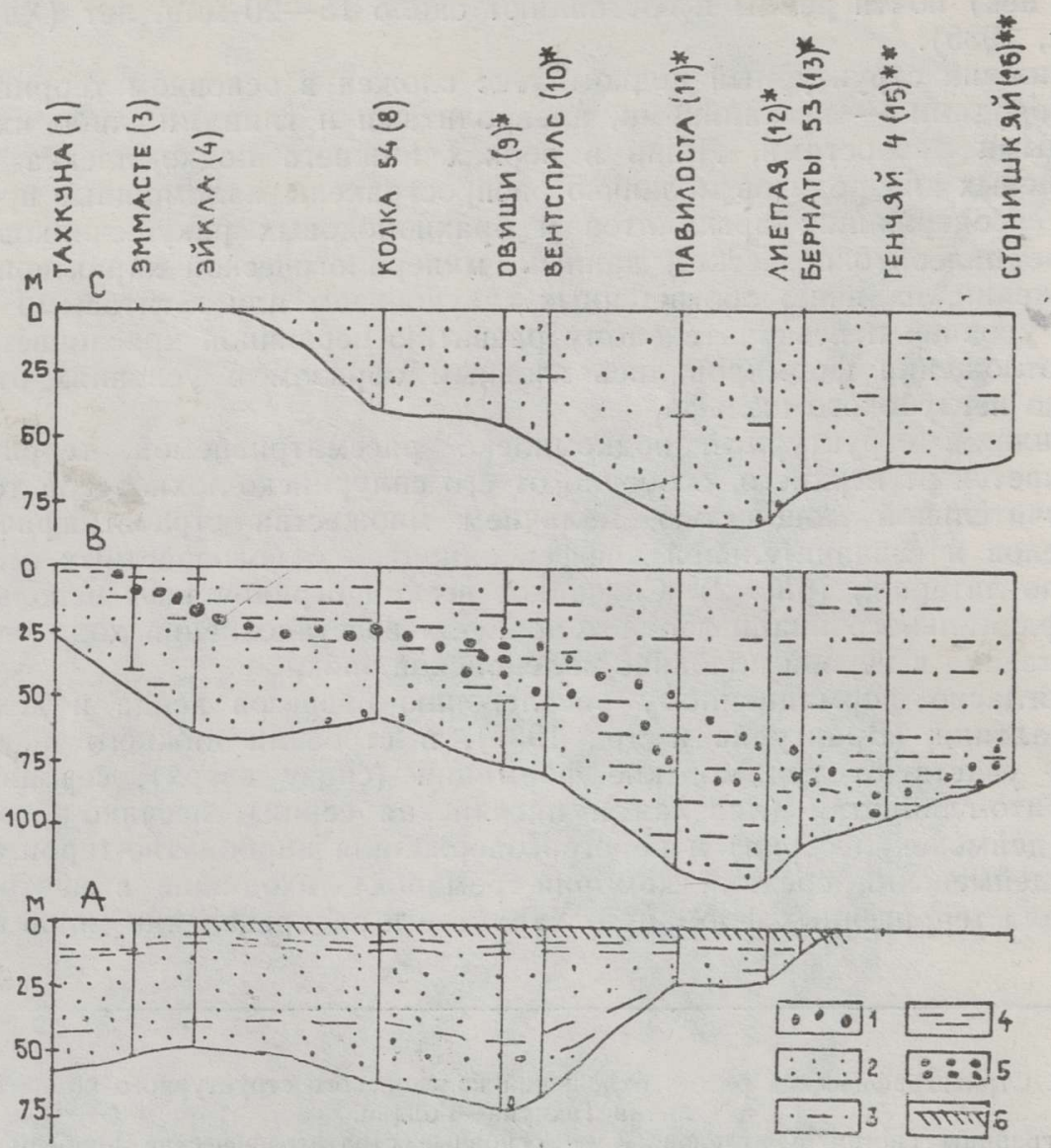

Рис. 3. Схема распределения мощностей и типов пород отложений ливской $(A)$, айсчяйской $(B)$ и дейменской $(C)$ серий по линин Тахкуна-Стонишкяй.

Верхние поверхности отложений отдельных этапов осадконакопления приведены по данным современных мощностей без учета постседиментационного размыва.

1 - крупнозернистые песчаники и гравелиты, 2 - мелкозернистые песчаники и крупнозернистые алевролиты, 3 - чередование алевролитов и глин, 4 - глины, 5 гётитовые оолиты, 6 - следы выветривания.

* По материалам А. Брангулиса (1985), ** - Т. Янкаускаса (1991).

Fig. 3. Distribution, thickness, and main lithological features of the deposits of the Liivi $(A)$, Aisčiai $(B)$, and Deimena $(C)$ sedimentary stages along the Tahkuna-Stoniškiai line.

Upper surfaces of sedimentary stages are shown without considering post-sedimentation denudation.

1 - sandy gravelstone, 2 - fine-grained sandstone and coarse-grained siltstone, 3 - alternation of silty and argillaceous rocks, 4- clay, $5-$ goethitic ooids, 6 - traces of weathering.

* Stratigraphy based mainly on Brangulis (Брангулис, 1985) and ** on Jankauskas (Янкаускас, 1991). 
С целью выявления влияния основных тектонических факторов седиментогенеза на формирование нижнего подкомплекса, помимо сводного профиля всего каледонского структурного комплекса (рис. 2), составлены профили по отдельным этапам осадконакопления более низкого порядка (Менс, 1981). Два нижних профиля (рис. $3, A, B)$ иллюстрируют изменения мощностей и состава отложений ливской и айсчяйской серий, вместе составляющих сероцветную алеврито-глинистую формацию; следующий (рис. 3, C) отражает эти показатели перекрывающих отложений дейменского этапа, выделенных в качестве песчаноалевритовой формации. По постдейменским отложениям, из-за ограниченной площади их распространения и незначительной мощности (рис. 2) на линии Тахкуна-Стонишкяй, профили не составлялись.

Сравнивая строение и состав отложений отдельных этапов осадконакопления на данной линии, можно прийти к следующим выводам:

1. Погружение рассматриваемой территории и, соответственно, формирование бассейна осадконакопления каледонского этапа начались с северных районов. Так, в разрезе Тахкуна нижний структурный комплекс начинается отложениями ливской серии, а южнее скв. Бернаты 53 - айсчяйской.

2. Стратиграфическая полнота и мощность нижнего подкомплекса наращиваются с севера до середины Балтийской синеклизы (скв. Лиепая), за исключением отложений керогенсодержащей карбонатно-терригенной формации. Это, по крайней мере на южном склоне Балтийского щита, а частично и на других участках, связано с постседиментационными размывами отложений, обусловленными чередующимися разнонаправленными тектоническими движениями в первой половине каледонского этапа развития.

3. Гранулометрический состав пород наводит на мысль, что на месте современных положительных макроструктур - Балтийского щита (во всяком случае его южной части) и Мазурско-Белорусской антеклизы - в первую половину каледонской эпохи была еще не суша, а относительно мелководный палеобассейн.

4. Начало формирования Елгавской впадины, расположенной в современном структурном плане в Лиепайско-Псковской антиклинальной зоне, связано с ранним кембрием. В айсчяйское и дейменское времена эта впадина испытывала наиболее интенсивное погружение.

Позднекаледонский структурный подкомплекс состоит из двух толщ - ордовикской и силурийско-лохковской. Они отделены друг от друга четким перерывом в седиментации, обусловленным глобальными эвстатическими движениями ашгильского оледенения. Названные толщи отличаются по продолжительности формирования, мощностям, строению, составу отложений и стратиграфической полноте разрезов.

Ордовикская глинисто-карбонатная толща максимальной мощностью 172 м в разрезе скв. Лиепая (рис. 2) имеет возраст (без тремадока) около 50 млн. лет (Харленд и др., 1985). На основе особенностей состава и характера распределения пород в вертикальном разрезе, позволяющих судить о тектоническом режиме седиментации в ордовикском бассейне, выделены три стадии развития посттремадокского ордовикского палеобассейна (I-III на рис. 4). В общих чертах они соответствуют стадиям развития посттремадокского ордовикского Палеобалтийского моря, выделенным X. Нестором (Nestor, 1990). Продолжительность каждой из этих стадий развития примерно 15-20 млн. лет, согласно датировкам Харленда и др. (1985). Хотя по новейшим датировкам ордовикских отложений (Cowie, Bassett, 1989) продолжительность лишь одного аренигского века составляет по меньшей мере 20 млн. лет, 


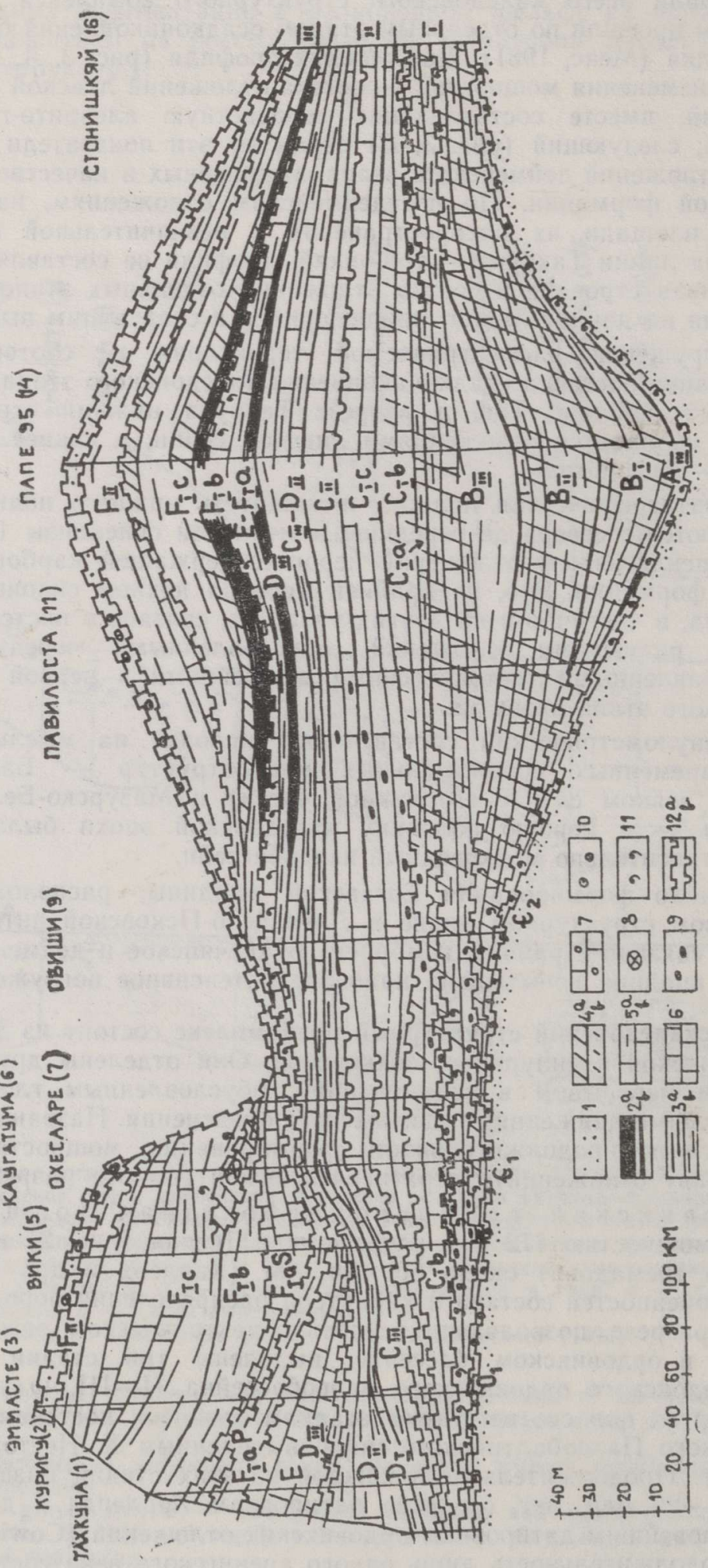


По вещественному составу и строению ордовикская глинисто-карбонатная толща расчленяется по латерали на Әстонскую и ШведскоЛатвийскую (или Центральную) главные структурно-фациальные (конфациальные) зоны (Мянниль, 1966; Jaanusson, 1976). Первая из них расположена на южном склоне Балтийского щита и представлена разрезами скважин Тахкуна, Курису, Эммасте, Вики, Каугатума (рис. 4). Вторая конфациальная зона находится в Балтийской синеклизе и представлена разрезами скважин Павилоста и Папе 95 (рис. 4). Между Эстонской и Шведско-Латвийской конфациальными зонами и южнее последней имеются еще две переходные зоны, разрезы которых (скважины Охесааре и Колка 54 на севере и скв. Стонишкяй на юге) сложены набором как мелководных, так и относительно глубоководных отложений.

Отложения нач альной стад и и $\left(\mathrm{A}_{\mathrm{III}}-\mathrm{C}_{\mathrm{I}} \mathrm{a}\right)$ Эстонской конфациальной зоны представлены мелководными серочветными терригенными, терригенно-карбонатными и карбонатными породами и имеют незначительную мощность. Характерно присутствие значительного количества глауконита, оолитов и разновыраженных четких поверхностей перерыва.

Рис. 4. Разрез посттремадокских ордовикских отложений между скважинами Тахкуна и Стонишкяй.

I-III - отложения главных стадий седиментации: I - трансгрессии-регрессии, II унификации, III - дифференциации.

Стратиграфические индексы горизонтов: $\mathrm{A}_{\text {III }}$ - варангуский, $\mathrm{B}_{\mathrm{I}}$ - латорпский, $\mathrm{B}_{\mathrm{II}}$ волховский, $\mathrm{B}_{\mathrm{III}}$ - кундаский, $\mathrm{C}_{\mathrm{I}} \mathrm{a}$ - азериский, $\mathrm{C}_{\mathrm{I}} \mathrm{b}$ - ласнамягиский, $\mathrm{C}_{\mathrm{I}} \mathrm{C}$ ухакуский, $\mathrm{C}_{\text {II }}$ - кукрузеский, C III - идавереский, $\mathrm{D}_{\mathrm{I}}$ - йыхвиский, $\mathrm{D}_{\text {II }}$ - кейлаский, $\mathrm{D}_{\mathrm{III}}$ - оандуский, $\mathrm{E}$ - раквереский, $\mathrm{F}_{\mathrm{I}} \mathrm{a}$ - набалаский $\left(\mathrm{F}_{\mathrm{I}} \mathrm{aP}\right.$ - паэкнаская св., $\mathrm{F}_{\mathrm{I}} \mathrm{aS}-$ сауньяская св.), $\mathrm{F}_{\mathrm{I}} \mathrm{b}$ - вормсиский, $\mathrm{F}_{\mathrm{I}} \mathrm{C}$ - пиргуский, $\mathrm{F}_{\mathrm{II}}$ - поркуниский.

Преобладающие породы: 1 - кварцевые песчаники, алевролиты; 2 - керогенистые граптолитовые аргиллиты $(a)$ и глинистые мергели $(b) ; 3$ - мергели: глинистые $(a)$, известковые $(b) ; 4$ - разные карбонатные и карбонатно-глинистые породы: красноцветные $(a)$ и пестроцветные $(b) ; 5$ - сероцветные известняки: глинистые комковатые $(a)$, чистые органогенные $(b) ; 6$ - афанитовые известняки; 7 - чередующиеся зернистые иловые известняки и седиментационные доломиты; 8 - биогермы; 9 гётитовые оолиты и псевдооолиты; 10 - фосфатные оолиты; 11 - глауконит; 12 пробелы: основные, доказанные биостратиграфически $(a)$, и менее значительные, связанные со стратиграфическими границами $(b)$.

Разрезы Овиши, Павилоста и Папе 95 даны согласно данным Р. Ж. Ульст и др. (1982); скв. Стонишкяй - по Ю. Л. Киснерюсу (1974).

Fig. 4. Cross section of the Post-Tremadoc Ordovician rocks between the Tahkuna and Stoniškiai borings.

I-III - main sedimentary development stages: I - transgressive-regressive, II unification, III - differentiation.

Stratigraphic indexes of stages: $A_{I I I}-$ Varangu, $B_{I}$ - Latorp, $B_{I I}$ - Volkhov, $\mathrm{B}_{I I I}$ - Kunda, $\mathrm{C}_{I} \mathrm{a}$ - Aseri, $\mathrm{C}_{I} \mathrm{~b}$ - Lasnamägi, $\mathrm{C}_{\mathrm{I}} \mathrm{c}$ - Uhaku, $\mathrm{C}_{\mathrm{II}}$ - Kukruse, $\mathrm{C}_{I I I}$ - Idavere, $\mathrm{D}_{\mathrm{I}}$ - Jõhvi, $\mathrm{D}_{\mathrm{II}}$ - Keila, $\mathrm{D}_{\mathrm{III}}$ - Oandu, E - Rakvere, $\mathrm{F}_{\mathrm{I}} \mathrm{a}$ - Nabala $\left(F_{I} a P\right.$ - Paekna Fm., $F_{I} a S$ - Saunja Fm. $), F_{I} b-$ Vormsi, $F_{I} C$ - Pirgu, $F_{I I}-$ Porkuni.

Dominating rocks: 1 - quartzose sandstones and siltstones; 2 - kerogenous graptolitic argillites $(a)$ and argillaceous marlstones $(b) ; 3$ - marlstones: argillaceous $(a)$, calcareous $(b) ; 4$ - different carbonate and carbonate-argillaceous rocks: redcoloured $(a)$, multicoloured $(b)$; 5 - grey limestones: argillaceous nodular $(a)$, pure bioclastics $(b) ; 6$ - aphanitic limestones; 7 - intercalated grained or micritic limestones and sedimentary dolomites; 8 - bioherms; 9 - goethitic ooids and pseudo-ooids; 10 - phosphatic ooids; $11-$ glauconite; $12-$ gaps: distinguished in faunal and facies changes $(a)$, stratigraphically weakly expressed $(b)$. 
Разрезы начальной стадии Шведско-Латвийской конфациальной зоны сложены более глубоководными, преимущественно красноцветными карбонатно-глинистыми и глинисто-карбонатными породами, включающими редкие зерна глауконита, железистые (гётитовые) оолиты и псевдооолиты (Ульст и др., 1982). Частые перерывы в осадконакоплении с ясными стратиграфическими пробелами для этой зоны нетипичны.

Отложения переходных зон, по сравнению со Шведско-Латвийской, менее глинистые, часто пестроцветные и включают хорошо прослеживаемые перерывы в седиментации.

Отложения с редн ей ст ад и и $\left(\mathrm{C}_{\mathrm{I}} \mathrm{b}-\mathrm{D}_{\mathrm{II}}\right)$ сравнительно однородные как по вертикальному разрезу, так и по площади. Они представлены органогенно-детритовыми и глинистыми карбонатными породами относительно выдержанной мощности (на рассматриваемом профиле менее 50 м). Лишь в верхах разреза преобладают глинистые известняки и мергели, присутствуют также частые прослои метабентонитов. Последние обязаны вулканической деятельности в соседней геосинклинальной области на западе, которая, вероятно, сопровождалась или предшествовала новой тектонической активности на окраине платформы и обусловила некоторую перестройку структурного плана в конце второй или в начале третьей стадии развития ордовикского Палеобалтийского моря.

Отложения поздней стадии $\left(\mathrm{D}_{\mathrm{III}}-\mathrm{F}_{\mathrm{II}}\right)$, подобно образованиям первой, характеризуются хорошо выраженной фациальной зональностью. Так, отложения Эстонской конфациальной зоны, где они наиболее мощные (94 м в скв. Эммасте), сложены в основном афанитовыми и детритово-глинисто-карбонатными породами, местами включающими рифовые образования. Отложения Шведско-Латвийской конфациальной зоны, которая в поздней стадии испытала погружение и некомпенсированное осадконакопление, сложены керогенсодержащими аргиллитами, глинистыми мергелями и красноцветными глинисто-карбонатными породами, а местами сероцветными известняками.

В переходных конфациальных зонах мощности отложений поздней стадии развития моря сильно сокращены, вплоть до выклинивания отдельных частей разреза.

В конце данной стадии развития ордовикского бассейна, в условиях обмеления, отлагались органогенно-детритовые известняки, включающие мелководные породы с песчаной примесью и фосфатными оолитами, а местами также прослои горючих сланцев. Это - отложения отгороженного шельфа и отмельно-баровых фациальных зон. Они встречены в верхах всего профиля.

Таким образом, весь карбонатный ордовик в районах распространения как сравнительно глубоководных (Шведско-Латвийская конфациальная зона), так и более мелководных маломощных и прерывистых отложений (Эстонская конфациальная зона) отражает полный цикл осадконакопления сравнительно высокого порядка. Различия в строении этого циклита между обеими зонами обусловлены разной интенсивностью и нередко разного знака колебательными движениями, обусловившими, с одной стороны, разную глубину бассейна седиментации, а с другой - разную глубину постседиментационного денудационного вреза.

С ил у рий ско-лохко в ск а я толщ а, продолжительностью формирования 35-40 млн. лет, подразделяется на рассматриваемом профиле по преобладающему тектоническому режиму и особенностям седиментации на три крупных подразделения, отражающих основные стадии развития бассейна (Эйнасто, 1986). 
В отложениях пе р в ой с т а и и $\left(\mathrm{G}_{1-2}-\mathrm{G}_{3}\right)$ выделяются по латерали три макрофации (рис. 5):

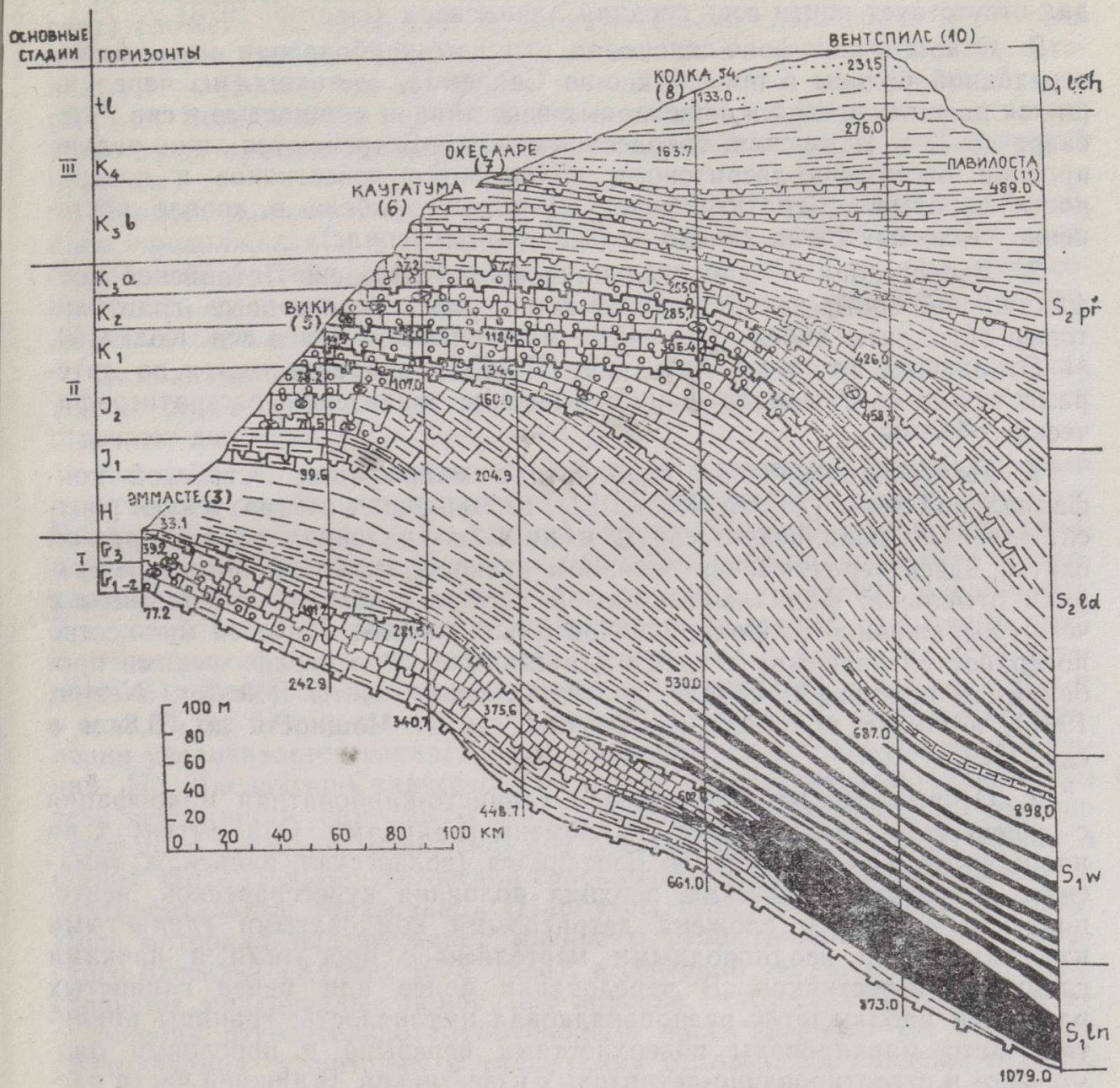

Рис. 5. Фациальный профиль силурийско-лохковских отложений по линии ЭммастеПавилоста.

I-III стадии развития: I - трансгрессия с дифференциацией локальных структур, II - стабилизация, III - заполнение.

Индексы горизонтов: $\mathrm{G}_{1-2}$ - юуруский, $\mathrm{G}_{3}-$ райккюлаский, $\mathrm{H}$ - адавереский, $\mathrm{J}_{1}-$ яаниский, $\mathrm{J}_{2}-$ яагарахуский, $\mathrm{K}_{1}-$ роотсикюлаский, $\mathrm{K}_{2}-$ паадлаский, $\mathrm{K}_{3} \mathrm{a}-$ курессаареский, $\mathrm{K}_{3} \mathrm{~b}$ - каугатумаский, $\mathrm{K}_{4}$ - охесаареский, $\mathrm{tl}$ - тильжеский. Условные обозначения см. на рис. 4.

Fig. 5. The Silurian-Lochkovian facies section on the ground of main sedimentary development stages between the Emmaste and Pavilosta borings.

I-III sedimentary stages: I - transgression with differentiation development of the local structures, II - stabilization, III - infilling.

Stratigraphic indexes of stages: $\mathrm{G}_{1-2}$ - Juuru, $\mathrm{G}_{3}$ - Raikküla, $\mathrm{H}$ - Adavere, $\mathrm{J}_{1}$ - Jaani, $\mathrm{J}_{2}$ - Jaagarahu, $\mathrm{K}_{1}-$ Rootsiküla, $\mathrm{K}_{2}-$ Paadla, $\mathrm{K}_{3} \mathrm{a}$ - Kuressaare, $\mathrm{K}_{3} \mathrm{~b}$ - Kaugatuma, $\mathrm{K}_{4}$ - Ohesaare, $\mathrm{tl}$ - Tilže.

Legend see Fig. 4. 
1. Мелководно-морская карбонатная макрофация в пределах Эстонской конфациальной зоны (варболаская, тамсалуская, райккюлаская свиты). На севере (юго-западе о-ва Хийумаа) она включает биогермный массив, большое количество пиритизированных поверхностей перерыва, частые прослои чистодетритовых и обломочно-биоморфных пород и в пограничных слоях юуруского и райккюлаского горизонтов также биогермы. В кровле значительный стратиграфический пробел: на выходах отсутствует почти весь средний лландовери (Нестор, 1976).

2. Открыто-шельфово-склоновая глинисто-карбонатная макрофация переходной полосы в пределах о-ва Сааремаа, состоящая из чередующихся пачек мергелей и афанитовых известняков мощностью в скв. Охесааре до 73 м (ыхнеская, саардеская свиты). Встречаются лишь редкие прослои биоморфно-детритового, обломочного известняков и поверхности перерыва. Стратиграфический объем пробела в кровле постепенно уменьшается на юг (до нуля в скв. Вентспилс).

3. Депрессионная глинистая макрофация Шведско-Латвийской конфациальной зоны, которая включает черные керогеновые граптолитовые аргиллиты добельской свиты мощностью 28,3 м в скв. Колка 54.

Отложения в торой с т а и и $\left(\mathrm{H}-\mathrm{K}_{3} \mathrm{a}\right)$ подразделяются по латерали также на три макрофации, имеющие значительные стратиграфические объемы.

1. Мелководно-морская карбонатная макрофация Эстонской конфациальной зоны (до скв. Колка 54), включающая яағарахускую, роотсикюласкую, паадласкую свиты и нижнюю половину курессаареской свиты. Здесь чередуются в основном разнообразные зернистые известняки отмельной фациальной зоны н лагунные первичные доломиты с четко выраженной разнопорядковой цикличностью. Имеется множество поверхностей перерыва с тремя длительными стратиграфическими пробелами в подошве и кровле роотсикюлаской свиты (Nestor, Nestor, 1991), а также в кровле паадлаской свиты. Мощность до 69,8 м в скв. Каугатума.

2. Открыто-шельфово-склоновая глинисто-карбонатная макрофация с существенно скользящими во времени границами. Она вытянута по площади от о-ва Хийумаа до Вентспилса (велизеская, яаниская, яамаская, сырвеская, торгуская, верхняя половина курессаареской, вентспилсская свиты) и сложена детритовыми комковатыми глинистыми известняками и неоднородными мергелями с прослоями и пачками глинистых известняков. В чередовании более или менее глинистых разностей наблюдается разнопорядковая цикличность; границы шиклитов часто маркированы поверхностями перерыва и прослоями биоморфно- и отсортированно-детритовых известняков. В нижней части рассматриваемой макрофации прослеживаются частые прослои метабентонитов, аналогично синфазным отложениям $\mathrm{C}_{\text {III }}$ и $\mathrm{D}_{\mathrm{I}}$ среднего ордовика. Характеризуется богатым по групповому и видовому составу комплексом органических остатков. Максимальная мощность до 235 м в скв. Колка 54.

3. Депрессионная керогенисто-глинистая макрофация (юрмальская, рижская, часть дубийской свиты), распространяющаяся южнее скв. Колка 54, представлена темно-серыми граптолитовыми керогенистыми глинистыми мергелями и аргиллитами со строго горизонтальной микрослойчатостью; мошность выдержанная - 200-220 м.

В силурийских отложениях т ре тьей ст ади и (Ks $\mathrm{b}-s t n)$ выделяются две макрофации:

1. Открыто-шельфовая карбонатно-глинистая макрофация (каугатумаская, охесаареская, часть минияской и таргальской свит) сложена неоднородными слоистыми мергелями с изменчивой карбонатностью, 
частыми прослоями и линзами обломочных, бноморфно-детритовых и микритовых известняков мощностью до 20-30 см, а на границах мезоциклитов также пачками чистодетритовых и комковатых глинистых известняков, на севере даже микрослойчатых домеритов отгороженного шельфа. Мощность этих пачек не превышает $3-4$ м. Максимальная мощность отложений всей макрофации в скв. Вентспилс 145 м.

2. Склоновая глинистая макрофация (часть минияской и юраской свит) сложена однородными зеленовато-серыми глинистыми мергелями и глинами с быстро нарастающей на юго-запад мощностью (скв. Стонишкяй - 420 м), что составляет около половины всего силурийского разреза. Встречаются редкие линзы и комки микритового глинистого известняка, прослои биоморфно-детритовых известняков темпеститовой природы.

Процесс заполнения остаточного бассейна с постепенным обмелением продолжался и в начале раннего девона - в лохковском веке. Лохковский бассейн унаследован от пөзднесилурийского, при этом сократилась его площадь и несколько изменился характер осадков: увеличилась доля песчано-алевритовых пород.

В лохковском веке отчетливо выделяются две фазы: тильжеская (t1) и стонишкяйская (stn), которым в наиболее полных разрезах отвечают два комплекса пород (рис. 2 и 5 ).

Комплекс пород тильжеского времени в северной части профиля представлен карбонатно-терригенными и терригенными породами (скв. Колка 54, Вентспилс). В нижней части Польско-Литовской синеклизы преобладающими для нижней части разреза являются пестроцветные бескарбонатные алевритовые глины и глинистые алевролиты. В верхней части разреза, гомимо вышеперечисленных отложений, прослеживаются прослои карбонатных алевролитов и домеритов (скв. Стонишкяй). Мощность отложений заметно увеличивается с севера (30 м в скв. Колка 54) на юг (107 м в скв. Стонишкяй). В этом же направлении увеличивается глинистость и уменьшается песчанистость отложений. На Лиепайско-Салдусском поднятии отложения отсутствуют. По всей вероятности, они смыты последующими денудациями. По мнению некоторых исследователей, морские отложения присутствуют только в осевой части Польско-Литовской синеклизы, а в северной части имеются континентальные образования (Нарбутас, 1984, 1987; Иголкина, 1981). Наш материал подтверждает мнение о существовании единого морского бассейна (Куршс, 1975, 1986), в северной части которого распространены мелководные прибрежно-морские отложения, а в южной отложения относительно глубоководной части шельфа. На всей рассматриваемой территории в тильжеских отложениях найдены остатки морской фауны. Чешуи телодонтов тильжеского возраста обнаружены также в пограничных слоях силура-девона более северных районов в девонском базальном конгломерате скв. Рухну, где сами отложения тильжеского времени отсутствуют.

По минеральному составу терригенной части изучаемые отложения коррелируются довольно хорошо. По-видимому, терригенный материал поступал из единого источника, расположенного на севере, поскольку минеральный компіонент отложений северных районов отличается большей разнородностью.

Стонишкяйские отложения отлагались в остаточном, неоднократно подвергавшемся осушению бассейне, располагавшемся только в Польско-Литовской синеклизе. Они представлены чередующимся комплексом красноватых глинистых и доломитовых алевролитов, глин и домеритов. Поступление терригенного материала происходило с севера, причем источник сноса во времени изменялся мало.

В конце лохковского века осадконакопление на северо-западе Во- 
сточно-Европейской платформы прекратилось. Началась продолжительная геократическая эпоха, охватившая в Прибалтике практически весь пражский век.

Подытоживая вышеизложенное по второй половине верхнего подкомплекса, следует подчеркнуть целостность силурийско-лохковского крупного этапа как тектонико-эвстатического цикла в развитии седиментации Балтийского бассейна с тремя не похожими друг на друга стадиями:

1. $\mathrm{G}_{1-2}-\mathrm{G}_{3}$ продолжительностью 7 млн. лет, со слабым привносом терригенного материала и некомпенсированным прогибанием всей краевой части платформы, образующая на стабильном шельфе целостный трансгрессивно-регрессивный цикл седиментации с последующим размывом, особенно на северо-западе Эстонии.

2. Н- $\mathrm{K}_{3}$ а продолжительностью 15 млн. лет, с умеренным терригенным привносом и относительной тектонической стабильностью, когда происходило боковое заполнение унаследованной от первой стадии впадины с миграцией бровки шельфа не менее чем на 350 км в сторону депрессии, широким развитием в отмельной зоне органогенных построек и в отгороженной мелководной зоне седиментационных доломитов.

3. $\mathrm{K}_{3} \mathrm{~b}$-stn продолжительностью 15 млн. лет, со всеусиливающимся привносом терригенного материала с поднимавшихся Каледонских гор и общей регрессией, что привело к постепенному заполнению остаточной впадины к концу каледонской эпохи.

В конце силурийско-лохковского времени наступили континентальные условия, существенно изменился структурный план и произошел интенсивный размыв развивавшегося регионального Лиепайско-Псковского поднятия. Это связано с замыканием Япетуса, коллизией континентов и главной фазой орогенеза в каледонидах (Зоненшайн, Приставкина, 1989), что означало завершение каледонской эпохи. Новая морская трансгрессия с востока в эмсе связана уже с герцинским этапом тектонического развития рассматриваемой территории.

Анализ материалов каледонского структурного комплекса запада Прибалтики выявляет главные факторы, определившие ход седиментации.

1. Формирование бассейна осадконакопления каледонского этапа развития рассматриваемой территории началось с севера с постепенным смещением центра прогибания на юг по оси времени.

2. Седиментация была обусловлена не только основными тектоническими и эвстатическими факторами, но и развитием локальных структур.

3. Первая и начало второй половины каледонского этапа характеризуются незначительным погружением дна бассейна и небольшими скоростями накопления осадков. В остальное время второй половины шло интенсивное прогибание дна бассейна и постепенное его заполнение вначале терригенно-карбонатными, а затем и все более чистыми терригенными осадками.

4. Современное распространение осадков и их мощности во многом зависят от интенсивности постседиментационной денудации, неоднократно имевшей место в течение каледонского этапа развития на северо-западе Восточно-Европейской платформы. 
Брангулис А. П. 1985. Венд и кембрий Латвии. Рига, Зннатне, 136.

Брангулис А. П., Коркутис В. А., Менс К. А., Пиррус Э. А. 1987. Терригенные формации венда и кембрия Прибалтики. - В кн.: Тектоника, фации и формации запада Восточно-Европейской платформы. Ред. Р. Г. Гарецкий, П. И. Сувейздис. Минск, Наука и техника, 65-73.

Зоненшайн Л. П., Приставкина С. И. (ред.). 1989. Геологическая история территории СССР и тектоника плит. Москва, Наука, 203.

Иголкина Н. С. (ред.). 1981. Геологические формации осадочного чехла Русской платформы. - Тр. ВСЕГЕИ, 296, 168.

Киснерюс Ю. Л. 1974. Опорный разрез скважины «Стонишкяй» Литовской ССР. Вильнюс, Периодика, 201.

Куршс В. М. 1975. Литология и полезные ископаемые терригенного девона главного поля. Рига, Зннатне, 216.

Куршс В. М. 1986. Ряды фациальных типов осадков и условия захоронения рыб в ранне-среднедевонских бассейнах Латвии. - В кн.: Биофации и фауна силурийского и девонского бассейнов Прибалтики. Отв. ред. А. П. Брангулис. Рига, Зинатне, 61-72.

Менс K. A. 1981. Об этапности осадконакопления в раннем кембрии Прибалтики. Изв. АН СССР. Сер. геол., 3, 82-90.

Менс К. А., Пиррус Э. А. 1979, Южный склон Балтийского щита. - В кн.: Стратиграфия верхнедокембрийских и кембрийских отложений запада ВосточноЕвропейской платформы. Отв. ред. Б. М. Келлер, А. Ю. Розанов. Москва, Наука, $7-41$.

Мянниль P. М. 1966. История развития Балтийского бассейна в ордовике. Таллинн, Валгус, 200.

Нарбутас B. B. 1984. Красноцветная формация нижнего девона Прибалтики и Подолии. Вильнюс, Мокслас, 136.

Нарбутас B. B. 1987. Условия образования красноцветных формаций в раннем и среднем девоне Прибалтики. - В кн.: Тектоника, фации и формации запада Восточно-Европейской платформы. Ред. Р. Г. Гарецкий, П. И. Сувейздис. Минск, Наука и техника, $134-140$.

Нестор В. 1976. Сопоставление некоторых разрезов райккюлаского горизонта Эстонии по микропланктону. - Изв. АН ЭССР. Хим. Геол., 25, 4, 319-324.

Решение Межведомственного регионального стратиграфического совещания по кембрийским отложенням Русской платформы (г. Вильнюс, 1983 г.). 1986. Ленинград, 49.

Решения Межведомственного стратиграфнческого совещания по ордовику и силуру Восточно-Европейской платформы 1984 г. с региональными стратиграфическими схемами. 1987. Ленинград, 114.

Тектоника Прибалтикн. 1979. - Тр. ЛитНИГРИ, вып. 33. Отв. ред. П. Сувейздис. Вильнюс, Мокслас, 92.

Ульст Р. Ж., Гайлите Л. К., Яковлева В. Н. 1982. Ордовик Латвин. Рига, Зинатне, 294.

Харленд У. Б., Кокс А. В., Ллевеллин П. Г., Пиктон К. А., Смит А. Г., Уолтерс Р. 1985. Шкала геологического времени. Москва, Мир, 139.

Эйнасто Р. Э. 1986. Основные стадии развития и фациальные модели силурийского краевого бассейна Балтики. - В кн.: Теория и опыт экостратиграфии. Ред. Д. Л. Кальо, Э. Р. Клааманн. Таллинн, Валгус, $37-54$.

Янкаускас T. 1991. Биостратиграфия пограничных отложений нижнего и среднего кембрия в Литве. - Изв. АН Әстонии. Геол., 40, 4, 152-159.

Cowie, J. W., Bassett, M. G. 1989. Global stratigraphic chart with geochronometric and magnetostratigraphic calibration. - Episodes, 12, 2 (chart).

Jaanusson, V. 1976. Faunal dynamics in the Middle Ordovician (Viruan) of BaltoScandia. - B кн.: The Ordovician System. Proceedings of a Paleontological Association symposium. Birmingham, Sept. 1974. Univ. Wales Press, Cardiff, $301-326$.

Nestor, H. 1990. Basin development and facies models. - B кн.: Field Meeting Estonia 1990. An Excursion Guidebook. Inst. Geol. Estonian Acad. Sci., Tallinn, 33-36.

Nestor, V., Nestor, H. 1991. Dating of the Wenlock carbonate sequences in Estonia and stratigraphic breaks. - Proc. Estonian Acad. Sci. Geol., 40, 2, 50-60.

Rzhonshitskaya, M. A. 1988. Biostratigraphic scheme of the Devonian of the Russian platform. - В кн.: Devonian of the World, Vol. III, Calgary, Alberta, Canada, $691-701$. 


\section{KALEDOONILISE STRUKTUURIKOMPLEKSI LÄBILOIGE TAHKUNA-GOLDAPI JOONEL}

On antud kaledoonilise tektoonilise etapi settimise põhijooned Läänemere idakaldal Põhja-Hiiumaast Kirde-Poolani.

Kaledoonia ea settebasseini kujunemine algas vaadeldava ala põhjaosast ja nihkus aeglaselt lōunasse. Selles suunas suureneb ka basseini põhja vajumiskiirus. Settebasseini intensiivsem vajumine toimus siluris, millega kaasnes kompenseerimata settimine.

Kaledoonilise struktuurikompleksi tänapäevane levikupilt ja paksus on peale settimisaegsete tektooniliste ning keskkonnatingimuste määratud suures osas ka settimisjärgse denudatsiooni ulatusega.

Kaisa MENS, Anne KLEESMENT, Silvi MAGI, Tõnis SAARDE, and Rein EINASTO

\section{CALEDONIAN STRUCTURAL COMPLEX ALONG THE TAHKUNA-GOLDAP LINE}

The Caledonian structural complex of the East Baltic area has been studied in order to establish the outlines of the sedimentation during the whole tectonic stage. This complex, including the rocks of the early Cambrian to the early Devonian age, is relatively well represented in the East Baltic area. It lies unconformably on rocks of different ages and is separated from the underlying and overlying strata by considerable sedimentation hiatuses.

In order to examine the continuity in sedimentation and the frequency, duration, and character of hiatuses in the Caledonian sequence, a cross section from Tahkuna (northern Hiiumaa) to Goldap (northeastern Poland) has been compiled (Figs. 1 and 2).

Mainly on the basis of lithological features, the Caledonian structural complex is divided into two subcomplexes separated by the boundary coinciding with that between the Tremadoc and Arenig series.

The lower subcomplex, formed approximately during the first half of the Caledonian epoch, is dominated by terrigenous rocks (Fig. 3) deposited in shallow-water conditions, generally at low sedimentation rates. It is stratigraphically incomplete having numerous hiatuses, due to which the thickness of the subcomplex is only one fifth of the total sequence in the studied area.

The upper subcomplex is mainly represented by argillaceous-carbonate rocks and is in turn subdivided into two parts: Ordovician and Silurian-Lochkovian. In the Ordovician and Silurian carbonate sequences, three lithologically distinct intervals of probably different tectonic and sedimentary origins have been distinguished (Figs, 4 and 5). As to its sedimentological features the Ordovician part (Fig. 4) is a kind of transitional link: its thickness is still small, although long-ranging hiatuses are missing, the sequence becomes stratigraphically more complete, and different facies belts can be observed.

The Silurian-Lochkovian part is characterized by stratigraphical continuity and great thickness, particularly in the southern sections (Figs. 2 and 5), well traceable facies belts, and short-term hiatuses.

In conclusion we can point out the following:

(1) subsidence of the basin shifted from north to south which is well reflected in the stratigraphy of the basal beds;

(2) the general features of sedimentation were determined by the elements of the regional as well as local structures;

(3) differences in the distribution and thickness of sediments, mostly caused by eustatic and tectonic factors, also depend on the extent of the postsedimentation denudation;

(4) lithological characteristics and thickness suggest prolonged subsidence during the Caledonian epoch in the Liepaja elevation area. 